\title{
PENGEMBANGAN PENDIDIKAN AGAMA
} BERKEARIFAN LOKAL DI TANAH ULAYAT BADUY

\section{DEVELOPMENT OF RELIGIOUS STUDIES WITH LOCAL WISDOM IN BADUY CUSTOMARY LAND}

\author{
Muhamad Murtadlo \\ Puslitbang Pendidikan Agama dan Keagamaan \\ Badan Litbang dan Diklat Kemenag RI \\ Email: tadho25@gmail.com
}

Naskah diterima 30 Januari 2017, direvisi 15 Februari 2017, disetujui 30 Maret 2017

\begin{abstract}
Every citizen is entitled to a decent and friendly education. The research questions are formulated to find a model of religious education with local wisdom. The study was conducted on the residents of Baduy Customary Land in Kampung Cicakal Girang, Kakes, Lebak Banten. The study was done by Participatory Research Action (PAR) approach. This study results in the conclusion that the development of education service access in Baduy People and certain tribes in Indonesia needs a special approach and in its implementation needs to accommodate local cultures in the development of school culture.
\end{abstract}

Keywords: Baduy tribe, education service, local wisdom

\begin{abstract}
Abstrak
Setiap warga negara berhak memperoleh pendidikan yang layak dan ramah. Pertanyaan penelitian dirumuskan untuk menemukan model pendidikan agama yang berkearifan lokal. Kasus penelitian dilakukan pada masyarakat penduduk di Tanah Ulayat Baduy di Kampung Cicakal Girang, Kakes, Lebak Banten. Pendekatan kajian yang dilakukan dengan pendekatan parcipatory Research Action (PAR). Penelitian ini menghasilkan kesimpulan bahwa pengembangan akses layanan pendidikan pada Suku Baduy dan suku-suku tertentu di Indonesia diperlukan pendekatan khusus; serta dalam pelaksanaannya perlu mengakomodasi budaya lokal dalam pengembangan budaya sekolah.
\end{abstract}

Kata-kata kunci: Suku Baduy, layanan pendidikan, kearifan lokal. 


\section{PENDAHULUAN}

Pendidikan merupakan kebutuhan dasar (basic need) bagi setiap warga negara. UUD 1945 dalam bab XIII pasal 31 ayat 1 mengamanatkan bahwa setiap warga negara berhak memperoleh pendidikan atau pengajaran yang layak. Dalam UU Sisdiknas No. 20 tahun 2003 pada bab IV pasal 5 ayat 1 disebutkan bahwa setiap warga negara berhak memperoleh pendidikan yang bermutu. Uraian ini jelas memperlihatkan bahwa setiap warga negara dimanapun mereka tinggal berhak memperoleh layanan pendidikan yang layak dan memadai, terlepas mereka merupakan masyarakat perkotaan yang modern maupun masyarakat dalam kategori marjinal yaitu masyarakat tertinggal, di pinggiran bahkan masyarakat di daerah terpencil.

Amanat undang-undang tersebut dalam kenyataan di lapangan belum terealisasi secara sempurna. Sampai saat ini masih banyak kelompok masyarakat yang belum memperoleh pelayanan pendidikan dengan baik, seperti mereka yang tinggal di daerah terpencil atau marginal. Kelompok marginal bisa diidentifikasi tidak saja berdasarkan agama, tetapijugaberdasarkan etnik, gender, akses dan semacamnya. Marginalisasi adalah fenomena ketidakseimbangan dalam pemerolehan peluang dalam aspek ekonomi, sosial dan pendidikan oleh sekumpulan masyarakat (Alcock 1993). Marginalisasi bersumber daripada berbagai faktor yang saling berkait dan kompleks. Akibat dari marginalisasi inilah, masyarakat tersebut menjadi miskin dan berada dalam keadaan serba naif. Masyarakat yang marginal ini mendapat peluang yang terbatas akibat daripada ketidakupayaan mereka dalam beberapa aspek yang akhirnya memberi kesan negatif kepada akuisisi hasil kemajuan negara. ${ }^{1}$

Salah satu kelompok sosial yang dipandang marginal saat ini adalah kelompok etnis yang memang jauh dari menikmati hasil atau dampak dari pembangunan yang dijalankan oleh negara. Salah satu kelompok etnis dimaksud adalah keberadaaan suku Baduy di Lebak Banten. Masyarakat Baduy merupakan salah satu suku di Indonesia yang sampai sekarang masih mempertahankan nilai-nilai budaya dasar yang dimiliki dan diyakininya, di tengah-tengah kemajuan peradaban di sekitarnya. Orang Baduy adalah kelompok masyarakat adat Sunda di Desa Kanekes, wilayah Kabupaten Lebak, Banten. Sebutan "Baduy" merupakan sebutan yang diberikan oleh orang luar kepada kelompok masyarakat tersebut. Berawal dari sebutan para peneliti Belanda yang agaknya mempersamakan mereka dengan kelompok Arab Badawi yang merupakan masyarakat yang berpindah-pindah (nomaden). Kemungkinan lain adalah karena adanya Sungai Baduy dan Gunung Baduy yang ada di bagian utara dari wilayah tersebut. Mereka sendiri lebih suka menyebut diri sebagai urang Kanekes atau "orang Kanekes" sesuai dengan nama wilayah mereka, atau sebutan yang mengacu kepada nama Kampung mereka seperti Urang Cibeo. ${ }^{2}$

Dari latar belakang di atas, riset aksi yang dibiayai oleh Puslitbang Pendidikan agama dan keagamaan Kementerian Agama

1 Alfitri, Buku Pembangunan Marginal eprints. unsri.ac.id/5265/1/ buku_pembangunan_ marginal. pdf .dikutip 10 September 2017

${ }^{2}$ Ita Suryani. 2014. Menggali Keindahan Alam Dan Kearifan Lokal Suku Baduy, Jurnal Musâwa, Vol. 13, No. 2, Desemer, h. 180-181. 
RI tahun anggaran 2011-2012 mengambil fokus pada Suku Baduy di Desa Cicakal Girang, Leuwidamar Lebak, Banten. Desa ini berada di wilayah Baduy tepatnya di Tanah Ulayat Baduy yang jauh dari kemodernan dan kekuasaan. Kebijakan pengembangan pendidikan semacam ini dilakukan sebagai upaya untuk menjembatani adanya deskriminasi dan ketidakseimbangan pemerataan kesempatan (memperoleh layanan pendidikan).

Pertanyaan penelitian dirumuskan bagaimana mengembangkan lembaga pendidikan Islam di daerah marginal dan mengembangkan pendidikan bernuansa budaya lokal? Untuk menjawab permasalahan tersebut, penelitian ini menggunakan tehnik Participatory Action Research (PAR) atau riset aksi. Riset aksi dalam pandangan tradisional adalah suatu kerangka penelitian pemecahan masalah, dimana terjadi kolaborasi antara peneliti dengan client dalam mencapai tujuan (Kurt Lewin,1973 disitasi Sulaksana,2004). Sasaran yang dipilih dalam pengembangan lembaga pendidikan Islam di daerah marginal dan bernuansa budaya lokal, dipilih Suku Baduy di Desa Kanekes, Kecamatan Leuwidamar, kabupaten Lebak, Banten.

Riset aksi ini dianggap penting, mengingat anak-anak yang ada pada masyarakat suku Baduy belum memiliki akses yang mudah dijangkau untuk dapat melanjutkan pendidikan setelah lulus MI tidak terpenuhi. Ini disebabkan karena wilayah ini merupakan wilayah terpencil dan belum memiliki lembaga pendidikan setingkat SLTP. Sementara lembaga pendidikan yang ada jaraknya sekitar $10 \mathrm{KM}$ dan hanya dapat ditempuh dengan jalan kaki, karena kondisi alamnya yang merupakan wilayah pegunungan. Di sisi lain, di kalangan suku Baduy masih ada penolakan terhadap sistem pendidikan modern. Oleh karena itu pengembangan model pendidikan yang menyesuaikan konteks pada budaya suku ini perlu dilakukan, sebagai upaya untuk mempermudah akses bagi masyarakat suku Baduy untuk memperoleh pendidikan yang lebih baik.

Pilihan pada Suku Baduy Desa Kanekes, Leuwidamar, Lebak Banten ini didasarkan pada beberapa pertimbangan sebagai berikut: 1) perlunya akses pendidikan diberikan kepada semua anak bangsa di daerah-daerah terpencil seperti suku-suku terisolir dan daerah-daerah perbatasan negara; 2) Suku Baduy adalah salah satu suku yang terisolir dan belum mendapatkan akses pendidikan yang memadai karena lokasi yang sulit dijangkau kendaraan; 3) Suku Baduy mempunyai karakteristik budaya tertentu yang membutuhkan pendekatan khusus untuk melakukan pendidikan kepada warganya.

Studi ini dilakukan selama dua tahun yaitu 2011-2012. Penelitian ini dilakukan dengan metode Participatory Action Research (PAR), yaitu penelitian yang dilakukan di lapangan sekaligus melakukan usaha pemberdayaan. Beberapa tahapan dilakukan dalam penelitian ini antara lain studi awal, pemberian stimulasi, pelaksanaan, monitoring, dan evaluasi.

Secara konseptual, pendidikan agama yang ada dalam judul di atas dimaksudkan sebagaimana tercantum dalam PP No. 55 Tahun 2007. Disebutkan bahwa Pendidikan agama adalah pendidikan yang memberikan pengetahuan dan membentuk sikap, kepribadian, dan keterampilan peserta didik dalam mengamalkan ajaran agamanya, yang 
dilaksanakan sekurang-kurangnya melalui mata pelajaran/kuliah pada semua jalur, jenjang, dan jenis pendidikan.

Selanjutnya dari bingkai konsep di atas, maka mengingat bahwa suku Baduy menganut keagamaan yang disebut Slam Sunda Wiwitan, Nasarudin Umar menyebutnya semacam islamnya versi Baduy, ${ }^{3}$ dikuatkan oleh kesimpulan Kesuma dkk (2012) yang menyatakan ada kedekatan ajaran Slam Sunda Wiwitan dengan ajaran tertentu dalam Islam, ${ }^{4}$ maka pendidikan agama di sini selanjutnya diarahkan pada pengembangan pendidikan agama Islam di Tanah Ulayat Baduy. Beberapa jenis lembaga pendidikan yang banyak berkembang dalam komunitas muslim di Indonesia adalah pesantren, pendidikan diniyah dan pendidikan madrasah. Dalam konteks riset aksi ini, pengembangan pendidikan Islam yang dimaksud adalah pendidikan madrasah. Pilihan madrasah didasarkan permintaan sebagian masyarakat di Tanah Ulayat Baduy di Cicakal Girang.

Kelompok masyarakat marginal, seperti suku Baduy ini, seharusnya mendapat prioritas sehingga mereka bisa mendapat akses yang sama terhadap sumber daya. Karena sesungguhnya mereka adalah manusia yang memiliki hak yang sama dalam meraih kesempatan. Bahwa manusia dilahirkan dengan bahasa tertentu, dengan jenis kelamin tertentu, di daerah tertentu, dengan bahasa tertentu, bahkan agama

${ }^{3}$ Nasaruddin Umar. 2015. “Agama \& Kepercayaan Lokal: Agama Slam Sunda Wiwitan” http://mozaik. inilah.com/read/detail/2199382/agama-slamsunda-wiwitan\#sthash.fVn9auIP.dpuf

4 Kesuma. 2009. Sobby, Arsyad. Fenomena Konversi Agama pada Komunitas Suku Baduy Banten (makalah). tertentu bukanlah menjadi hambatan bahwa orang bersangkutan tidak lebih berharga dari lainnya. Tapi dalam kenyataan, mereka sampai saat ini masih banyak yang belum memperoleh kesempatan, termasuk kesempatan layanan pendidikan yang layak. Ini terjadi karena adanya diskriminasi kebijakan terutama oleh pemerintah yang kurang memberi kesempatan pada masyarakat tersebut untuk memperoleh layanan pendidikan sebagaimana masyarakat lainnya.

Berkearifan lokal adalah sikap, pandangan dan kemampuan suatu komunitas di dalam mengelola lingkungan rohani dan jasmaninya yang memberikan kepada komunitas tertentu itu memiliki daya tahan dan daya tumbuh di dalam wilayah di mana komunitas itu berada. Dengan kata lain kearifan lokal adalah jawaban terhadap situasi geografis-politishistoris dan situasional yang bersifat lokal. ${ }^{5}$

Adapun dalam konteks kearifan lokal, maka usaha perwujudan pengembangan akses pendidikan madrasah dicari bentuknya dalam gaya yang berkekhasan budayalokal di Baduy, Lebak Banten. Pertanyaannya adalah apakah lembaga pendidikan madrasah bisa disamakan penyelenggaraaanya dibandingkan dengan madrasah di lokasi lain?. Kalau ada itu bentuknya seperti apa? Tulisan ini mencoba menelusuri pasang surut inisiatif mendirikan lembaga pendidikan keagamaan dan bagaimana hubungannya dengan kondisi sosial budaya sekelompok masyarakat yang kita teliti.

5 Permana. 2010. Eka Cecep. Kearifan Lokal Masyarakat Baduy Dalam Mitigasi Bencana. Wedatama Widya Sastra. Jakarta. h. 1 
Beberapa penelitian tentang masyarakat di Tanah Ulayat Baduy ini antara lain Ita Suryani yang menyatakan bahwa nilai kearifan lokal dijunjung tinggi oleh suku Baduy. Masyarakat Baduy sangat menjaga keseimbangan dan keselarasan dengan alam. mereka sangat menjunjung tinggi ajaran tentang menjaga alam serta melestarikan. Selain itu, masyarakat Baduy tidak mengeksploitasi alam. Mereka memanfaatkan alam seperlunya yang ada di alam dan disertai dengan pelestarian. ${ }^{6}$ Karena itu, mereka cenderung tidak menginginkan perubahan atau modernisasi kehidupan sosial budaya mereka.

Penelitian Asnawati berjudul "Pelayanan Administrasi Kependudukan bagi Komunitas Adat Baduy." Penelitian ini menyebutkan sudah ada pencatuman agama Slam Sunda Wiwitan dalam KTP yang ditandatangani oleh Camat. Artinya kebijakan pemerintah daerah pada saat itu telah mulai mengakomodir keberadaan agama slam Sunda Wiwitan dalam administrasi sipil. ${ }^{7}$

Penelitan lain oleh Fransisca Nur'aini Krisna berjudul Studi Kasus Layanan Pendidikan Nonformal Suku Baduy. Penelitian ini menemukan beberapa permasalahan dalam menyelenggaraan pendidikan nonformal antara lain meliputi : (a) keterbatasan dana untuk penyelenggaraan berbagai jenis pendidikan nonformal; (b) tingkat kehadiran warga belajar yang masih rendah; (c) penolakan kehadiran pendidikan nonformal

${ }^{6}$ Ita Suryani. 2014. Menggali Keindahan Alam Dan Kearifan Lokal Suku Baduy, Jurnal Musâwa, Vol. 13, No. 2, Desemer, h. 180-181.

Asnawati, Pelayanan Administrasi Kependudukanbagi Komunitas Adat Baduy. Jurnal Harmoni, Vol. 13, No. 1 Tahun 2014. oleh tetua adat; dan (d) pengaturan jadwal belajar sering tidak tepat, karena adanya waktu-waktu adat. ${ }^{8}$

Posisi utama kajian ini adalah melengkapi kajian-kajian yang sudah ada. Bedanya terletak pada usaha perintisan pendidikan formal di Tanah Ulayat baduy. Usaha pengembangan akses pendidikan yang pilihan jatuh ke pendidikan formal, justru datang dari sebagian masyarakat yang tinggal di Tanah Ulayat Baduy, yaitu di dusun Cicakal Girang.

\section{Tahapan Riset Aksi}

Riset Aksi atau sering disebut Participatory Action research (PAR) merupakan teknik untuk merangsang partisipasi masyarakat peserta program dalam berbagai kegiatan, mulai dari tahap analisa sosial, perencanaan, evaluasi, hingga perluasan program. ${ }^{9}$ Mengikuti tahapan ini, narasi tulisan tentang riset aksi ini disusun sesuai dengan tahapan tersebut.

\section{Mengenal Masyarakat dan Suku di Tanah Ulayat Baduy}

Langkah pertama riset aksi yang kami lakukan, sesuai dengan tahapan di atas adalah analisis sosial, yakni mengenali suku Baduy. Dari studi awal, pemukiman Suku Baduy terletak di Kabupaten Lebak dan menempati Tanah Ulayat di Desa Kanekes, Lebak, Banten. Jarak dari Jakarta ke lokasi ini kurang lebih160 Km ke arah barat daya.

${ }^{8}$ Fransisca Nur'aini Krisna. 2014. Studi Kasus Layanan Pendidikan Nonformal Suku Baduy. Jurnal Pendidikan dan Kebudayaan, Vol. 20, No. 1.

9 Agus Afandi dkk. 2013. Modul Participatory Action Research (PAR) (Surabaya: Lembaga Pengabdian Masyarakat (LPM), h.57-58 
Ciri-ciri umum yang bisa dikenali untuk mengetahui budaya orang Baduy antara lain mereka menjauhi budaya modern, tidak bersekolah, kemana-mana merekajalan kaki. Hal ini didasari keyakinan bahwa mereka adalah kelompok oarang yang berada di alam kedua setelah alam nirwana dan sebelum alam ketiga (dunia fakta saat ini). Karena kepercayayan mereka ini mereka berusaha menyatu dengan alam dengan apa adanya tanpa sentuhan modernisasi dan tehnologi modern sama sekali.

Wilayah Tanah Ulayat suku Baduy di Kanekes secara geografis terletak pada koordinat 6 $27^{\prime} 27^{\prime \prime}$ - 6 6 $30^{\prime} 0^{\prime \prime}$ LS dan 108'3'9" - 106 4'55" BT (Permana, 2001). Mereka bermukim tepat di kaki pegunungan Kendeng di desa Kanekes, Kecamatan Leuwidamar, Kabupaten LebakRangkasbitung, Banten, berjarak sekitar $40 \mathrm{~km}$ dari kota Rangkasbitung. Wilayah yang merupakan bagian dari Pegunungan Kendeng dengan ketinggian $300-600$ m di atas permukaan laut (DPL) tersebut mempunyai topografi berbukit dan bergelombang dengan kemiringan tanah rata-rata mencapai $45 \%$, yang merupakan tanah vulkanik (di bagian utara), tanah endapan (di bagian tengah), dan tanah campuran (di bagian selatan). Suhu rata-rata $20^{\circ} \mathrm{C}$.Tiga desa utama orang Kanekes Dalam adalah Cikeusik, Cikertawana, dan Cibeo.

Suku Baduy merupakan suatu kelompok masyarakat Sunda, terletak di Kab. Lebak, Banten. Sebutan "Baduy" merupakan sebutan yang diberikan oleh penduduk luar kepada kelompok masyarakat tersebut, berawal dari sebutan para peneliti Belanda yang agaknya mempersamakan mereka dengan kelompok Arab Badawi yang merupakan masyarakat yang berpindah- pindah (nomaden). Kemungkinan lain adalah karena adanya Sungai Baduy dan Gunung Baduy yang ada di bagian utara dari wilayah tersebut. ${ }^{10}$ Mereka sendiri lebih suka menyebut diri sebagai urang Kanekes atau "orang Kanekes" sesuai dengan nama wilayah mereka, atau sebutan yang mengacu kepada nama Kampung mereka seperti urang Cibeo. ${ }^{11}$

Sejarah Suku Baduy, menurut berbagai sumber terdapat berbagai versi: versi pertama, menyebutkan mereka berasal dari sisa-sisa pasukan dari Kerajaan Padjajaran/ Bogor. Konon pada sekitar abad ke XI dan XII Kerajaan Pajajaran menguasai seluruh tanah Pasundan yakni dari Banten, Bogor, Priangan sampai ke wilayah Cirebon, pada waktu itu yang menjadi Raja adalah Prabu Bramaiya Maisatandraman dengan gelar Prabu Siliwangi. Dengan masuknya ajaran Agama Islam sekitar abad ke XV yang dibawa oleh para saudagar- dan salah seorang dari Wali Songo dalam hal ini Sunan Gunung Jati dari Cirebon, mulai dari Pantai Utara sampai ke selatan daerah Banten, menyebabkan kekuasaan Raja semakin terjepit dan rapuh dikarenakan rakyatnya banyak yang memasuki agama Islam. Akhirnya punggawa raja beserta para pengikutnya yang masih setia meninggalkan kerajaan dan masuk hutan belantara kearah selatan dan mengikuti hulu sungai, mereka

${ }^{10}$ Nurhadi Rangkuti 1988a 'Gelegak tradisi tua tanah Kanekes', dalam: Nurhadi Rangkuti (ed.), Orang Baduy Dari Inti Jagat, Jakarta: Bentara Budaya.pp. 9-15.

11 Garna, Y. 1993. Masyarakat Baduy di Banten, dalam Masyarakat Terasing di Indonesia, Editor: Koentjaraningrat \& Simorangkir, Seri Etnografi Indonesia No.4. Jakarta: Departemen Sosial dan Dewan Nasional Indonesia untuk Kesejahteraan Sosial dengan Gramedia Pustaka Utama. 
meninggalkan tempat asalnya dengan tekad seperti yang diucapkan pada pantun upacara Suku Baduy:

"Jauh teu puguh nu dijugjug, leumpang teu puguhnu diteang, malipir dina gawir, nyalindung dina gunung, mending keneh lara jeung wiring tibatan kudu ngayonan perang jeung paduduluran nu saturunan atawa jeung baraya nu masih keneh sa wangatua." Ujaran itu berarti: "jauh tidak menentu yang tuju (Jugjug), berjalan tanpa ada tujuan, berjalan ditepi tebing, berlindung dibalik gunung, lebih baik malu dan hina dari pada harus berperang dengan sanak saudara ataupun keluarga yang masih satu turunan."12 Keturunan ini yang sekarang bertempat tinggal di kampong Cibeo (Baduy Dalam) dengan ciri-ciri: berbaju putih hasil jahitan tangan (baju sangsang), ikat kepala putih, memakai sarung biru tua (tenunan sendiri) sampai di atas lutut, dan sipat penampilannya jarang bicara (seperlunya) tapir amah, kuat terhadap Hukum adat, tidak mudah terpengaruh, berpendirian kuat tapi bijaksana.

Senada dengan itu dikisahkan bahwa mereka berasal dari Banten Girang/ Serang. Menurut cerita yang menjadi senopati di Banten padawaktuituadalah putradariPrabu Siliwangi yang bernama Prabu Seda dengan gelar Prabu Pucuk Umun. Setelah Cirebon dan sekitarnya dikuasai oleh Sunan Gunung Jati ia mengutus putranya yang bernama Sultan Hasanudin bersama para prajuritnya untuk mengembangkan agama Islam di wilayah Banten dan sekitarnya. Situasi di Banten terasa terancam, sehingga Prabu

${ }^{12}$ Nurhadi Rangkuti 1988a 'Gelegak tradisi tua tanah Kanekes', in: Nurhadi Rangkuti (ed.), Orang Baduy Dari Inti Jagat, Jakarta: Bentara Budaya.pp. 9-15.
Pucuk Umun bersama para ponggawa dan prajuritnya meninggalkan tahta memasuki hutan belantara dan menyelusuri sungai Ciujung sampai ke Hulu sungai, maka tempat ini mereka sebut Lembur Singkur Mandala Singkah yang maksudnya tempat yang sunyi untuk meninggalkan perang dan akhirnya tempat ini disebut GOA/ Panembahan Arca Domas yang sangat dikeramatkan oleh komunitas Baduy. Keturunan orang-orang inilah yang kemudian menetap di Kampung Cikeusik (Baduy Dalam). ${ }^{13}$ Mereka dikenal berwatak keras, acuh, sulit untuk diajak bicara (hanya seperlunya), kuat berpegang terhadap hukum Adat, tidak mudah menerima bantuan orang lain yang sifatnya pemberian, memakai baju putih (blacu) atau dari tenunan serat daun Pelah, iket kepala putih memakai sarung tenun biru tua (diatas lutut).

Versi kedua, menyatakan bahwa mereka adalah penduduk asli daerah Baduy. Van Tricht, seorang dokter yang melakukan riset kesehatan tahun 1928, menyangkal pendapat komunitas Baduy berasal dari Kerajaan Sunda-Pajajaran. Menurutnya, mereka adalah penduduk asli di daerah tersebut. Orang Baduy pun "menolak" jika dikatakan bahwa mereka adalah orangorang pelarian Kerajaan Sunda-Pajajaran. ${ }^{14}$

Versi ketiga, mereka berasal dari Suku Pangawinan (campuran). yang dimaksud suku Pengawinan adalah dari percampuran suku-suku yang pada waktu itu ada yang berasal dari daerah sumedang, Priangan,

\footnotetext{
${ }^{13}$ Adimiharjo Kusnaka. 2000. Hak Sosial Budaya Masyarakat Adat, Yogyakarta; Lapera Pustaka Utama, h. 20.

${ }^{14}$ Baduy; Asal-usul dan Cara Mereka Hidup, lihat http://www.wacana.co/2015/10/baduy akses 22 April 2017.
} 
Bogor, Cirebon juga dari Banten. Menurut versi ini mereka terdiri dari orang-orang yang melangggar adat sehingga oleh Prabu Siliwangi dan Prabu Pucuk Umun dibuang ke suatu daerah tertentu. Golongan inipun ikut terdesak oleh perkembangan agama Islam sehingga kabur terpencar kebeberapa daerah perKampungan tapi ada juga yang kabur ke hutan belantara, sehingga ada yang tinggal di Guradog Kecamatan Maja, ada yang terus menetap di kampong Cisungsang Kecamatan Bayah, serta ada yang menetap di Kampung Sobang dan kampung Citujah kecamatan Muncang. Penduduk di tempattempat tersebut hingga kini masih ada kesamaan ciri khas tersendiri. Adapun sisanya sebagian lagi mereka terpencar mengikuti/menyusuri sungai Ciberang, Ciujung dan sungai Cisimeut yang masingmasing menuju ke hulu sungai, dan akhirnya golongan inilah yang menetap di 27 perKampungan di Baduy Panamping (Baduy Luar) desa Kanekes kecamatan Leuwidamar kabupaten Lebak dengan ciricirinya; berpakaian serba hitam, ikat kepala batik biru tua, boleh bepergian dengan naik kendaraan, berladang berpindah-pindah, menjadi buruh tani, mudah diajak berbicara tapi masih tetap setia pada hukum adat. ${ }^{15}$

Di Suku Baduy Panamping pada tahun 1978, pemerintah melaksanakan proyek PKMT (pemukiman kembali masyarakat terasing) yang lokasinya di Kampung Margaluyu dan Cipangembar desa Leuwidamar kecamatan Leuwidamar. Proyek ini terus dikembangkan oleh pemerintah di

${ }^{15}$ Abdurrahman Misno Bambang Prawiro. 2016. Reception Through Selection-Modification: Antropologi Hukum Islam di Indonesia. Yogyakarta; Deepublish, 2016, h. 126.
Kampung Kopo I dan II, Kampung Sukamulya dan Kampung Sukatani desa Jalupangmulya kecamatan Leuwidamar. Suku Baduy Panamping yang telah dimukimkan inilah yang kebanyakan adalah Muslim. Kelompok ini telah memeluk agama Islam, bahkan ada yang sudah melaksanakan rukun Islam yang ke 5 yaitu memunaikan ibadah Haji.

Penelitian ini menemukan masyarakat yang menempati Tanah Ulayat Baduy Desa Kanekes terdiri dari 3 kelompok, yaitu: 1) Suku Baduy Dalam yaitu Suku Baduy yang berdomisili di Tiga Tangtu (Kepuunan) yakni Cibeo, Cikeusik dan Cikertawana; 2) Suku Baduy Panamping yaitu Suku Baduy yang bedomisili di luar Tangtu yang menempati 27 Kampung di desa Kanekes yang masih terikat oleh hukum adat dibawah pimpinan Puuun (kepala adat); 3) Suku Baduy Muslim yaitu Suku Baduy yang telah dimukimkan dan telah mengikuti ajaran agama Islam dan prilakunya telah mulai mengikuti masyarakat luar serta sudah tidak sepenuhnya mengikuti hukum adat.

Dari kajian awal juga diketahui bahwa Suku Baduy mempunyai karakteristik budaya dan norma-norma sebagai berikut: 1) mereka berkeyakinan bahwa realitas ini terbagi menjadi 3, yaitu alam nirwana, alam tengah, dan alam nampak saat ini. Suku Baduy meyakini mereka sedang berada di alam tengah. Karenanya mereka tidak boleh mengikuti gaya hidup sebagaimana kemajuan manusia modern saat ini; 2) implikasi dari keyakinan itu, mereka tidak membolehkan warganya mengadaptasi hal-hal yang berbau modern seperti: sekolah, menonton TV, mendengar Radio, memanfaatkan HP bahkan bercocok tanam secara modern, irigasi;3) bagi siapa saja yang ingin hidup sebagaimana manusia modern 
umumnya, maka dia harus meninggalkan Suku Baduy dan keluar dari Tanah Ulayat Baduy di desa Kanekes.

Berangkat dari keyakinan seperti itu, maka pengembangan akses pendidikan, apalagi pendidikan formal yang ditawarkan negara pada warganya menjadi tidak punya peluang untuk masuk ke dalam kehidupan SukuBaduy. Akibat dari kenyataaninibanyak anak Suku Baduy yang tidak bisa membaca. Melihat fakta seperti itu, riset aksi ini terus mencari celah yang memungkinkan adanya proses transformasi ilmu yang masuk ke sebagian masyarakat yang tinggal di tanah ulayah Baduy.

Pilihan kemudian dijatuhkan ke masyarakatCicakalGirang. Wilayahini masih termasuk Tanah Ulayat Baduy dan akses pendidikan mereka sangatterbatas. Lembaga pendidikan yang ada di sana hanyalah lembaga sekolah 6 tahun. Kebetulan di sana ada Madrasah Masyarikul Huda. Masyarakat di sini juga yang menghendaki peningkatan akses pendidikan jenjang Sekolah Lanjutan Tingkat Pertama (SLTP).

\section{Memetakan Kebutuhan dan Pengembangan Akses Pendidikan}

Langkah kedua riset aksi ini adalah merencanakan dan merumuskan model pendekatan pengembangan akses pendidikan pada Suku Baduy, Lebak, Banten. Permasalahan pertama dihadapi adalah keyakinan suku Baduy. Suku Baduy mempunyai pandangan hidup yang menolak apa saja yang berbau modernisasi. Mereka menolak lembaga pendidikan yang dianggapnya merupakan agen modernisasi. Untuk itu, kegiatan ini menempuh sebuah pilihan bagian mana dari Suku Baduy ini yang paling mungkin untuk didekati untuk pengembangan akses pendidikan. Maka ketemulah sebuah titik dari Tanah Ulayat Baduy bernama Desa Cicakal Girang.

Mengapa dusun Cicakal Girang dipilih menjadi lokasi riset aksi? Pemilihan dusun Cicakal Girang sebagai lokasi riset aksi didasarkan fakta bahwa: 1) Cicakal Girang adalah dusun di Tanah Ulayat Baduy yang relatif berubah dan berbeda dengan Suku Baduy secara umum: menerima perubahan, menerimapendidikanmodern, penduduknya mengaku muslim; 2) Perubahan sosial yang terjadi di Cicakal Girang relatif kurang terarah; 3) Di Tanah Ulayat Baduy, program dari luar yang mungkin masuk hanya di dusun Cicakal Girang.

Lokasi Cicakal Girang ternyata sangat jauh dari akses kendaraan roda empat. Peneliti dan tim sempat dua kali mencoba mendekati sasaran. Baru kali yang kedua, tim peneliti berhasil mencapai desa sasaran. Itu karena dibantu naik ojek sejauh kurang lebih $5 \mathrm{Km}$. Sebagaimana telah disebutkan bahwa ternyata di dalam komunitas Baduy yang tinggal di Tanah Ulayat Baduy terdapat sebuah lokasi yang dihuni Baduy Muslim yang tinggal di dusun Cicakal Girang. Berdasarkan survei awal ini, di wilayah Baduy di Cicakal Girang ini adalah daerah paling mungkin untuk dikembangkan akses pendidikan. Selanjutnya, pilihan usaha pengembangan pendidikan lokal berbasis budaya lokal ini kami putuskan di dusun Cicakal Girang.

Masyarakat dusun Cicakal Girang, berbeda dengan dusun lain di wilayah Tanah Ulayat Baduy, umumnya adalah penganut Islam yang taat dan mau menerima perubahan. Hanya saja karena lokasi dusun 
Cicakal Girang ini jauh di pelosok, sehingga warga masyarakat di dusun ini juga dalam kondisi serba terbatas. Pendidikan yang ada di daerah itu baru sebatas pendidikan dasar 6 tahun, yaitu dengan keberadaan Madrasah Ibdtidaiyah Masyarikul Huda. Adapun untuk melanjutkan pendidikan bagi lulusan madrasah tersebut, warga harus menempuh perjalanan sejauh $15 \mathrm{Km}$. Akibatnya banyak anak lulusan MI itu yang memilih tidak melanjutkan pendidikan. Selama ini karena tidak adanya sekolah lanjutan seperti MTS/ sederajat, sebagian besar siswa yang lulus MI tidak melanjutkan sekolah. Belum lagi, alat transportasi menuju lokasi pendidikan sangat minim ditambah dengan akses jalan yang buruk dan berbukit-bukit.

Semula, kami datang tidak untuk menawarkan pengembangan pendidikan formal, namun lebih ingin memberikan pendampingan pendidikan yang dapat meningkatkan ketrampilan (Lifeskills) masyarakat setempat. Kegiatan itu bisa berupa pendidikan ketrampilan non formal. Kami menawarkan program seperti: pendidikan calistung (Membaca, Menulis dan Berhitung), pendidikan lifeskills sebagai penguatan tambahan bagi anak-anak usia sekolah, pendidikan diniyah dan pendidikan formal. Setelah berdiskusi dengan pemuka masyarakat setempat yang terdiri dari pengurus RW, pengelola pendidikan dari lembaga yang ada, ketua pemuda dan tokoh agama setempat, ternyata mereka lebih mengusulkan pembukaan pendidikan formal tingkat SLTP. Siswa MI Masyarikhul Huda sebagian besar sesungguhnya sangat berminat melanjutkan sekolah ke tingkat MTS/sederajat. Begitu pula dengan orang tua murid, mereka rata-rata mengharapkan anak-anaknya melanjutkan sekolah, sayangnya sekolah lanjutan yang ada, lokasinya jauh. Para orang tua mempunyai kesulitan pembiyaan bila harus bersekolah di tempat yang jauh.

Setelah mengerucut pada kebutuhan pengembangan akses pendidikan berupa pendidikan formal jenjang menengah pertama (MTs/SMP), maka segera kami mendiskusikan berbagai kebutuhan dasar penyelenggaraan pendidikan formal seperti kesulitan pengadaan guru, sistem kurikulum, keterbatasan sarana dan prasarana. Para tokoh lokal menyatakan sanggup untuk mencari dan mengadakan kebutuhan yang diperlukan. Maka pada forum itu pembicaraan difokuskan pada perintisan madrasah Tsanawiyah Cicakal Girang.

\section{Evaluasi Pengembangan Akses pendidikan}

Memperhatikan kondisi sosial Cicakal Girang di mana sudah berdiri MI Masyarikul Huda serta memperhatikan masukan dan saran masyarakat setempat yang menginginkan pelayanan pendidikan lanjutan setingkat SMP, maka tim peneliti Puslitbang Pendidikan Agama dan Keagamaan, Balitbang dan Diklat Kementerian Agama pada tahun 2011 mendesain model penyelenggaraan Madrasah Tsanawiyah (MTs) di Kampung Cicakal Girang, Desa Kanekes, Kecamatan Leuwidamar, Kabupaten Lebak, Propinsi Banten. Kegiatan ini dilakukan dalam rangka memenuhi amanat Undang-Undang Dasar 1945 atas hak dasar semua warga negara Indonesia terhadap pelayanan pendidikan.

Selanjutnya setelah dua tahun riset aksi pengembangan akses pendidikan 
madrasah dilakukan di Cicakal Girang, maka dilakukanlah perenacanaa terhadap hal-hal berikut: Bentuk, Pengelolaan, Kesiswaan, Pendidik, Pembelajaran, Kurikulum, dan Sarana Prasarana. Beberapa pelaksanaan sekaligus catatan evaluasi pengembangan akses pendidikan di Cicakal Girang dapat dijelaskan sebagai berikut:

Bentuk. Rintisan pengembangan akses pendidikan akhirnya ditentukan dengan mencobamerintis pendidikan formal jenjang SLTP. Maka dipilihlah bentuk pendidikan itu dalam aksi perintisan Madrasah Tsanawiyah. Riset aksi ini dilakukan selama dua tahun. Tahun pertama fokus pada usaha pembukaan lembaga pendidikan sebagaimana lembaga pendidikan pada umumnya. Tahun kedua, dipakai untuk membangun kekhasan lembaga pendidikan tersebut yang dibangun berbasis budaya lokal.

Tabel 1. Rencana Riset Aksi

Pengembangan Pendidikan Agama Berbasis Budaya Lokal

\begin{tabular}{lll}
\hline \multicolumn{1}{c}{ ASPEK } & \multicolumn{1}{c}{ Rencana } & \multicolumn{1}{c}{ Realisasi } \\
\hline Bentuk & $\begin{array}{l}\text { Pendirian Lembaga } \\
\text { Pendidikan Formal } \\
\text { atau non formal }\end{array}$ & $\begin{array}{l}\text { Dibuka Madrasah } \\
\text { Tsanawiyah (MTs) }\end{array}$ \\
\hline Pengelolaan & Terbentuk tim & Proses belajar- \\
& pengelola/guru dan & mengajar dimulai \\
& tenaga kependidikan & Pengusulan izin \\
& Menyelenggarakan & operasional \\
& proses belajar - & \\
& mengajar di MTs & \\
\hline Kesiswaan & Menarik siswa usia & Penguatan kerjasama \\
& MTs di dusun Cicakal & dengan pesantren \\
& Girang & yang ada di lokasi \\
& Menerima dari daerah & sebagai asrama siswa \\
& sekitar & \\
\hline Pendidik & Rekruitmen guru dari & Peningkatan \\
& dusun setempat & kompetensi pendidik \\
& Rekruitmen guru & melalui pelibatan \\
& pendukung dari luar & kegiatan pada forum- \\
& dusun & forum pendidikan \\
\hline Pembelajaran & Masuk Siang hari & Masuk siang \\
\hline
\end{tabular}

\begin{tabular}{|c|c|c|}
\hline Kurikulum & $\begin{array}{l}\text { Menggunakan } \\
\text { kurikulum reguler } \\
\text { sebagaimana } \\
\text { madrasah pada } \\
\text { umumnya }\end{array}$ & $\begin{array}{l}\text { Penguatan } \\
\text { penyusunan } \\
\text { kurikulum } \\
\text { Mengembangkan } \\
\text { KTSP (Kekhasan lokal) }\end{array}$ \\
\hline $\begin{array}{l}\text { Sarana } \\
\text { Prasarana }\end{array}$ & $\begin{array}{l}\text { Menggunakan balai } \\
\text { singgah sebagai } \\
\text { sekretariat } \\
\text { Menggunakan Gedung } \\
\text { Ml sbg tempat belajar } \\
\text { (masuk Siang) }\end{array}$ & $\begin{array}{l}\text { Pembebasan tanah } \\
\text { (Rintisan RKB) } \\
\text { Mencari Block Grand } \\
\text { untuk pembngunan } \\
\text { tempat belajar }\end{array}$ \\
\hline
\end{tabular}

Pengelolaan. Untuk pengelolaan ini dipilihlah ketua tim lokal, yang nantinya sekaligus menjadi kepala Madrasah Persiapan. Maka atas kesepakatan berbagai pihak dipilihlah ibu Dewi sebagai ketua pengelola/kepala madrasah.

Kesiswaan. Untuk tahap pertama dimulai dari semua lulusan MI yang ada, baik yang lulus tahun itu maupun tahun-tahun sebelumnya ditawari untuk menjadi siswa pertama. Karena kegiatan tahap pertama ini ada insentif dari tim peneliti bagi siswa baru berupa buku-buku dan tas sekolah, maka peminat tahap pertama ini cukup banyak. Bahkan calon siswa dari luar dusun pun berminat. Tercatat yang mendaftar 40 anak.

Pendidik. Untuk pendidik atau guru lembaga pendidikan MTs ini maka direkrutlah tim pengelola yang terdiri dari guru-guru dari dusun Cicakal Girang dan direkrut dari guru di luar dusun. Maka terkumpullah 12 guru, empat dari dusun Cicakal Girang, dan 8 dari dusun luar. Dari tim pengelola itu dipilih satu sebagai Kepala madrasah, yaitu Ibu Dewi. Setelah tim pengelola terbentuk, segera diusahakan izin operasional dari Kemenag kab Lebak diproses. Namun karena ada ketentuan bahwaizin operasional bisa diberikan setelah suatu lembaga menyelenggarakan proses belajar-mengajar sekurang-kurangnya 
selama 2 tahun, maka didahulukan aktifitas pembelajaran terlebih dahulu.

Pembelajaran. Karena belum adanya ruang belajar secara khusus, maka untuk sementara penyelenggaraan madrasah persiapan dilakukan pada siang hari dengan menggunakan gedung Madrasah Ibtidaiyah yang atas. Pelaksanaan dilakukan pada siang hari.

Kurikulum. Untuk sementara Madrasah ini menggunakan kurikulum yang telah digunakan oleh madrasah reguler pada umumnya. Penguatan secara khusus nantinya dilakukan dalam penyusunan kurikulum Tingkat satuan pendidikan (KTSP) dan perumusan muatan lokal. Khusus dalam perumusan muatan lokal ini akan diarahkan pada penguatan ciri khas budaya lokal.

Sarana. Untuk tahap awal penyelenggaraan digunakan fasilitas yang ada dan fasilitas yang dimiliki oleh Madrasah Ibtidaiyah Masyarikul huda. Fasilitas sosial yang dimiliki warga Cicakal Girang adalah rumah singgah, yaitu sebuah rumah yang dibangun untuk transit dan tempat yang bisa digunakan untuk menginap bagi siapapun pengunjung desa ini. Untuk pengembangan pendidikan ini, rumah tersebut dimanfaatkan sementara untuk kantor; sedangkan proses belajar-mengajar menggunakan fasilitas yang terdapat pada banguan Madrasah Ibtidaiyah yang ada.

\section{Perluasan Program: Pengembangan Pendidikan Bernuansa Budaya Lokal}

Sesuai dengan tujuan riset aksi ini, tujuan kedua adalah mengembangkan pendidikan bernuansa budaya lokal. Gagasan ini dianggap penting mengingat: 1) akomodasi budaya lokal terhadap komunitas yang awalnya menentang bentuk-bentuk pendidikan formal akan membantu proses jalannya dan sosialisasi pendidikan; 2) akomodasi nuansa lokal juga diperlukan mengingat lokasi sasaran berada di tanah dengan karakteristik dan ketinggiantertentu sehingga dibutuhkan model arsitektur yang selaras dengan alam, dan sebisa mungkin bangunan sekolah berbentuk bangunan yang tahan gempa.

Dalam rangka perumusan kekhasan karakteristik MTs Cicakal Girang ini, kami merumuskan beberapa kekhasan itu pada:

a) Nama lembaga; b) sistem pembelajaran; c) penampilan fisik; d) muatan lokal dalam kurikulum.

Nama Lembaga, Kekhasan yang berhasil diputuskan bersama masyarakat lokal dalam madrasah ini adalah masalah nama madrasah. Semula ada beberapa pilihan nama untuk MTs ini seperti nama yang disamakan dengan madrasah ibtidaiyah yang telah ada yaitu MTs Masyarikul Huda; nama dikaitkan dengan nama dusun yaitu MTs Cicakal Girang; atau nama madrasah yang bernuansa istilah atau tradisi Baduy.

Dari beberapa alternatif nama yang ada akhirnya dipilih opsi terakhir yaitu nama yang menggunakan istilah yang akrab dalam nilai-nilai Baduy. Maka berdasarkan pertimbangan ini dipilihlah nama "MTs Alam Wiwitan." Alam wiwitan adalah sebutan masyarakat Baduy yang meyakini bahwa suku Baduy merupakan penghuni alam kedua setelah alam nirwana. Mereka membagi alam ke dalam tiga kosmologi, yaitu alam pertama (nirwana), alam kedua yang diyakini suku Baduy sebagai alam mereka, dan alam ketiga, yaitu dunia faktual yang dihuni orang kebanyakan ini. 
Dengan menggunakan nama MTs Alam Wiwitan berarti lembaga pendidikan ini telah mengakomodasi keyakinan khas suku Baduy. Penggunaan nama Alam Wiwitan bagi madrasah dikandung maksud penjelasan bahwa madrasah adalah sumber utama bagi peserta didik mengenal dunia.

Sistem Belajar, Sekolah Alam, Terinspirasi dengan kultur Suku Baduy yang sangat dekat dengan alam dalam menjaga keseimbangan alam sebagaimana adanya dan menghindari intervensi manusia yang bersifat merusak alam, maka digagaslah sistem belajar yang lebih banyak mengandalkan alam sekitar. Dari sini muncul konsep sekolah alam yang layak diterapkan dalam pengembangan akses pendidikan ini. Hal itu dimulai dengan belajar di alam terbuka, sebagaimana sekarang dikenal konsep sekolah alam. Terhadap ide ini, MTs Alam Wiwitan mencoba mengembangkan konsep sekolah alam di Cicakal Girang.

Dalam praktiknya, sistem pembelajaran yang dijalankan oleh MTs Alam Wiwitan ini menggunakan dua model, yaitu sistem belajar di kelas; dan sistembelajar dialam.Hal ini dilakukan dalam rangka mengantisipasi kemungkinan cuaca seperti musim hujan yang tidak memungkinkan belajar di alam terbuka. Maka untuk keberlangsungan belajar secara reguler, maka pembelajaran dilakukan dengan menggunakan dua pendekatan tersebut.

Penampilan Fisik. Penampilan fisik yang akan digagas di MTs Alam Wiwitan diupayakan selaras dengan budaya atau tradisi yang dimiliki Suku Baduy.Penampilan fisik yang diselaraskan meliputi dua hal, yaitu: 1) seragam sekolah; dan 2) bangunan madrasah. Sejak program ini diluncurkan hingga tulisan ini dibuat, rencana seragam itu masih dalam pembahasan antara pihak pengelola madrasah dengan Jaro Daina. Menurut Jaro Daina penggunaan seragam khas Baduy apa tidak terlalu mencolok. Jaro Daina bukan melarang, hanya memberi pertimbangan bahwa penggunaan seragam khas batik Baduy terlalu ekpose. Karena pertimbangan itu, pimpinan madrasah masih menunda penggunaan seragam siswa dengan baju khas Baduy.

Penampilan fisik yang lain yang diharapkan adalah bentuk bangunan tempat pendidikan. Sesuai dengan tekstur lokasi Cicakal Girang yang berada di atas pegunungan, maka diharapkan bangunan yang dipilih adalah bangunan yang tahan gempa, syukur bagai mengikuti gaya arsitektur rumah panggung sebagaimana yang telah dipilih masyarakat Baduy.

Kurikulum Muatan lokal, Madrasah ini melayani tentu saja warga Baduy Muslim Cicakal Girang, lembaga ini juga melayani kebutuhan pendidikan untuk anak-anak dari dusun Manpelem di kecamatan yang sama yaitu Leuwidamar. Tidak saja kecamatan Leuwidamar, tetapi juga melayani dari kecamatan lain yaitu dusun Nanggeran, Cibeunyur, Kalirejo, Kebon Sawo yang masuk wilayah kecamatan Bojong Manik.

Adapun alasan mereka menempuh pendidikan di Cicakal Girang: 1) karena pertimbangan lokasi yang dekat dan dapat dijangkau dari rumah tinggal mereka; 2) alasan lain ada yang sekaligus memasukkan anak mereka ke pesantren yang ada di Cicakal Girang, yaitu pesantren Darul Huda. 
Tabel 2. Pengembangan Kekhasan Lokal Di MTs Alam Wiwitan, Cicakal Girang

\begin{tabular}{|c|c|c|}
\hline Kekhasan & Indikator & Realisasi \\
\hline $\begin{array}{l}\text { Nama } \\
\text { Lembaga }\end{array}$ & $\begin{array}{l}\text { Penggunaan istilah } \\
\text { yang selaras dengan } \\
\text { konteks sosial yang ada }\end{array}$ & $\begin{array}{l}\text { Madrasah ini kemudian } \\
\text { diberi nama Madrasah } \\
\text { Alam Wiwitan, selaras } \\
\text { dengan istilah Sunda } \\
\text { Wiwitan). }\end{array}$ \\
\hline $\begin{array}{l}\text { Model } \\
\text { pembelajaran }\end{array}$ & $\begin{array}{l}\text { Pengembangan model } \\
\text { belajar di alam terbuka } \\
\text { (sekolah alam) }\end{array}$ & $\begin{array}{l}\text { Terlaksana (belum di } \\
\text { dukung oleh saung- } \\
\text { saung) }\end{array}$ \\
\hline \multirow[t]{3}{*}{$\begin{array}{l}\text { Penampilan } \\
\text { Fisik }\end{array}$} & $\begin{array}{l}\text { Seragam anak } \\
\text { menggunakan baju } \\
\text { seragam dengan batik } \\
\text { khas Baduy }\end{array}$ & $\begin{array}{l}\text { Proses diskusi dengan } \\
\text { Pemimpin Suku Baduy } \\
\text { (jaro Daina) }\end{array}$ \\
\hline & $\begin{array}{l}\text { Seragam guru } \\
\text { menggunakan baju } \\
\text { seragam dengan batik } \\
\text { khas Baduy }\end{array}$ & $\begin{array}{l}\text { Pimpinan Madrasah } \\
\text { membiasakan } \\
\text { menggunakan busana } \\
\text { khas tenunan Baduy }\end{array}$ \\
\hline & $\begin{array}{l}\text { Bangunan gedung } \\
\text { (tahan gempa dan } \\
\text { rumah pangggung) atau } \\
\text { saung-saung }\end{array}$ & Belum terealisir \\
\hline \multirow[t]{3}{*}{$\begin{array}{l}\text { Kurikulum } \\
\text { (muatan lokal) }\end{array}$} & $\begin{array}{l}\text { Pengembangan seni } \\
\text { budaya khas Baduy: } \\
\text { seni angklung. }\end{array}$ & Terlaksana \\
\hline & $\begin{array}{l}\text { Pengembangan lifeskills } \\
\text { dengan membuat } \\
\text { kerajinan khas Baduy }\end{array}$ & $\begin{array}{l}\text { Terlaksana dengan } \\
\text { membuat gantungan } \\
\text { kunci dari tempurung }\end{array}$ \\
\hline & $\begin{array}{l}\text { Pengembangan sumber } \\
\text { ajar berupa buku-buku } \\
\text { cerita tentang nilai-nilai } \\
\text { khas Baduy }\end{array}$ & Belum terlaksana \\
\hline
\end{tabular}

\section{Hambatan dan Capaian Pengembangan Akses Pendidikan}

Setelah riset aksi penyenggaraan pendidikan formal di Cicakal Girang ini berjalan satu tahun dan pembelajaran berlangsung satu semester, maka mulai ditemukan beberapa permasalahan dalam pengembangan akses pendidikan tersebut. Beberapa permasalahan itu antara lain:

Pertama, keaktifan siswa. Dari sisi keaktifan siswa masih ditemukan banyak siswa yang tidak masuk kelas karena mereka masih diperintah orang tuanya untuk membantu di ladang dan sawah. Sebagian orang tua masih belum memahami penting pendidikan reguler bagi anak mereka.
Mereka masih beranggapan bahwa tugas utama anak adalah membantu orang tua.

Kedua, keterbatasan fasilitas pembelajaran. Mengingat daerahnya yang serba terbatas seperti tidak ada listrik yang memadai, maka pembelajaran sering terganggu. Di saat hujan turun, banyak siswa yang tidak masuk kelas dan seringkali kegiatan pembelajaran terpaksa dilakukan tanpa alat penerangan karena seringnya lampu mati. Para guru yang berdomisili di luar Cicakal Girang harus bersusah payah datang ke lokasi dengan transportasi yang terkendala karena licin. Akibatnya guru sering terlambat.

Ketiga, kompetensi Guru. Keterbatasan guru di daerah marginal seperti itu menyebabkan kegiatan pembelajaran ini diasuh oleh guru-guru seadanya. Keahlian guru masih terbatas mengingat kualifikasi dan kompetensi guru hanya mengandalkan tenaga guru yang ada. Rendahnya kopetensi guru diperparah oleh beberapa hal seperti: belum efektifnya kegiatan supervisi untuk bimbingan peningkatan kapasitas guru; Guru-guru yang mengajar masih banyak yang berpendidikan tigkat SLTA; sementara itu ditemukan guru yang berpendidikan S-1 pun masih belum sesuai dengan mata pelajaran yang diampu. Mereka juga kebanyakan belum dilatih profesi keguruan dan peningkatan kapasitas guru; Masih banyak guru yang belum mempersiapkan RPP untuk kegiatan pembelajaran. Guru masih mengajar seadanya dengan metode ceramah.

Keempat, Tempat Kegiatan Belajar Mengajar (KBM). Sampai saat ini, MTs Alam Wiwitan belum memiliki gedung sendiri yang memungkinkan kegiatan pembelajaran 
semakin kondusif. Kegiatan pembelajaran masih menumpang di MI Masyarikul Huda. Hal ini mengganggu jalannya pembelajaran dan siswa pun belajar di siang hari.

Terhadap masalah-masalah yang muncul, tim riset aksi mengantisipasi dengan meyakinkan kepada pengelola lokal bahwa itulah tantangan penyelenggaraan pendidikan di daerah khusus seperti Cicakal Girang. Tidak ada jalan lain kecuali meyakinkan bahwa pendidikan ini dilaksanakan untuk kemajuan wilayah itu dengan masalah yang memang harus dihadapi, kecuali program itu dibatalkan. Terhadap beberapa hal yang bisa ditingkatkan melalui pembinaan seperti kemampuan guru menyusun Rencana Pelaksanaan Pembelajaran (RPP), silabus, dan lain-lain maka tim riset mengupayakan pendampingan yang lebih intensif dengan meminta kepada Mapenda kemenag Kab. Lebak untuk melakukannya, termasuk kemungkinan memberikan dana tambahan untuk insentip guru.

Sementara itu, terkait dengan pengembangan pendidikan berbudaya lokal terkait dengan 4 (empat) hal yaitu nama lembaga, pembelajaran sistem alam, penampilan fisik, kurikulum muatan lokal dapat disampaikan bahwa permasalahan muncul pada selain nama lembaga.

Nama Lembaga. Pada lembaga keinginan untuk menggunakan nama Alam Wiwitan nampaknya tidak ada masalah yang berarti. Nama itu sudah dipakai dalam suratmenyurat lembaga pendidikan hasil riset aksi ini.

Sistem pembelajaran, nampaknya sistem ini hanya dijadikan opsi di luar pendidikan reguler di kelas. Warna dominan masih tetap pembelajaran berbasis kelas. Karena cuaca tertentu masih sering memaksa mereka untuk belajar di kelas.

Penampilan fisik. Pakaian dengan batik khas Baduy belum sepenuhnya terlaksana karena ada anggapan penggunaan seragam khas batik suku Baduy dipakai dalam penyelenggaraan pendidikan formal. Padahal selama ini, suku ini mempunyai paham menolak pendidikan formal.

Kurikulum Muatan Lokal. Kurikulum muatan lokal ini direncanakan melalui kurikulum pengembangan seni budaya khas Baduy yaitu alat musik angklung. Di samping itu direncanakan pengembangan lifeskills dengan membuat kerajinan khas Baduy dan Pengembangan sumber ajar berupa bukubuku cerita tentang nilai-nilai positif khas Baduy. Kegiatan ini belum terbilang sukses, walau sudah mulai dilakukan.

\section{PENUTUP}

Dari hasil riset aksi pengembangan layanan pendidikan agama pada masyarakat Tanah Ulayat Suku Baduy (Cicakal Girang), dapat diperoleh kesimpulan sebagai berikut: pertama, pengembangan akses layanan pendidikan pada suku-suku tertentu perlu pendekatankhusus. Padakasus suku Baduy di Lebak Banten, usaha pelayanan pendidikan mendapatkan resistensi (penolakan) tertentu terkait dengan keyakinan dan pilihan budaya mereka yang menolak budaya modernisasi; kedua, untuk tindak lanjut mewujudkan tujuan berbangsa, yaitu untuk mencerdaskan kehidupan bangsa maka riset aksi ini dikembangkan dalam konsep layanan pendidikan agama berkearifan lokal; ketiga, dalam rangka meningkatkan penerimaan suku lokal terhadap layanan pendidikan 
agama, maka perlu dalam pelaksanaannya dilakukan akomodasi budaya lokal dengan budaya sekolah.

Riset aksi ini, merekomendasikan bahwa: Pertama, dalam mengembangan akses pendidikan di kelompok marginal atau suku-suku tertentu perlu pendampingan khusus oleh Kementerian Agama dalam mewujudkan layanan pendidikan agama berkearifan lokal. Kedua, dalam melakukan pendampingan, usaha tersebut perlu diperjelas dengan dihadirkanya pedoman dan desain layanan pendidikan agama berkearifan lokal (suku budaya tertentu). Ketiga, perlu dilakukan kajian lanjutan untuk pengembangan layanan pendidikan agama di daerah khusus dan marginal dalam rangka meningkatkan usaha negara mencerdasakan anak bangsa. []

\section{UCAPAN TERIMA KASIH}

Atas telah selesainya riset aksi dan penulisan artikel ini, penulis merasa perlu mengucapkan terima kasih kepada Kepala puslitbang Pendidikan Agama dan Keagamaan yang telah menugaskan kami melakukan riset aksi di tanah ulayat Baduy. Terima kasih juga kami ucapkan atas kerjasama semua pihak yang terlibat dalam pelaksanaan riset aksi pengembangan pendidikan agama berkearifan local ini. Mereka itu adalah kepala RT Cicakal Girang, Pengelola MI Cicakal Girang; Kemenag Kabupaten Lebak, Banten; Dosen Pembimbing dari UIN Syarif Hidayatullah Jakarta. []

\section{DAFTAR PUSTAKA}

Afandi, Agus dkk. (2013): Modul Participatory Action Research (PAR) Surabaya, Lembaga Pengabdian Masyarakat (LPM),

Alcock, P. (1993): Understanding poverty. London, Mac Millan Press Ltd.

Asnawati. (2014): Pelayanan Administrasi Kependudukan bagi Komunitas Adat Baduy. Jurnal Harmoni, Vol. 13, No. 1

Garna, Y. (1993): Masyarakat Baduy di Banten, dalam Masyarakat Terasing di Indonesia, Editor: Koentjaraningrat \& Simorangkir, Seri Etnografi Indonesia No.4. Jakarta: Departemen Sosial dan Dewan Nasional Indonesia untuk Kesejahteraan Sosial dengan Gramedia Pustaka Utama,.

Ita Suryani, (2014): Menggali Keindahan Alam Dan Kearifan Lokal Suku Baduy, Jurnal Musâwa, Vol. 13, No. 2, Desemer

Kesuma, Sobby, Arsyad. (2009): Fenomena Konversi Agama pada Komunitas Suku Baduy Banten (makalah),

Krisna, Fransisca Nur'aini. (2014): Studi Kasus Layanan Pendidikan Nonformal Suku Baduy. Jurnal Pendidikan dan Kebudayaan, Vol. 20, No. 1.

Kusnaka, Adimiharjo. (2000): Hak Sosial Budaya Masyarakat Adat, (Yogyakarta; Lapera Pustaka Utama,

Permana.Eka.Cecep. (2010): Kearifan Lokal Masyarakat Baduy Dalam Mitigasi Bencana. Wedatama Widya Sastra, Jakarta .

Prawiro,Abdurrahman Misno Bambang (2016): Reception Through SelectionModification: Antropologi Hukum Islam di Indonesia, Yogyakarta, Deepublish, 
Rangkuti, Nurhadi. (1988): 'Gelegak tradisi tua tanah Kanekes', in: Nurhadi Rangkuti (ed.), Orang Baduy dari inti jagat, Jakarta, Bentara Budaya.

Sulaksana,U., (2004): Managemen Perubahan, Cetakan I, Pustaka Pelajar Offset, Yogyakarta.

Umar, Nasaruddin. (2015): “Agama \& Kepercayaan Lokal: Agama Slam Sunda Wiwitan" lihat http://mozaik.inilah. com/read/detail/2199382/
William, S. (1986): Exclusion: The Hidden Face of Poverty. Dalam Golding P (pnyt). Excluding the poor, him. 20-25. London, CPAG.

Baduy; Asal-usul dan Cara Mereka Hidup, lihat http://www.wacana.co/ 2015/10/ baduy akses 22 April 2017. 